\title{
IMPROVED STOCK UNEARTHING METHOD (ISUM) ALLOW TO ASSESS SOIL EROSION PROCESSES IN GRAFTED PLANTS USING IN SITU TOPOGRAPHICAL MEASUREMENTS
}

\section{EL MÉTODO MEJORADO DEL TOCÓN (ISUM) PERMITE EVALUAR PROCESOS DE EROSIÓN DEL SUELO EN PLANTAS INJERTADAS UTILIZANDO MEDIDAS TOPOGRÁFICAS IN SITU}

\author{
Jesús Rodrigo-Comino ${ }^{a,{ }^{*}}$, Enric Terol ${ }^{b}$, Artemi Cerdàc \\ a Departamento de Análisis Geográfico Regional y Geografía Física, Facultad de Filosofía y Letras, Campus Universitario de Cartuja, \\ Universidad de Granada, 18071 Granada, Spain. jesusrc@ugr.es \\ ${ }^{\mathrm{b}}$ Department of Cartographic Engineering, Geodesy and Photogrammetry, Universitat Politècnica de València, Camino de Vera s/n, \\ 46022 Valencia, Spain. eterol@cgf.upv.es
}

c Soil Erosion and Degradation Research Group, Department of Geography, University of Valencia, 46010 Valencia, Spain. artemio.cerda@uv.es

\begin{abstract}
:
Policymakers, stakeholders and rural inhabitants must be aware of the relevance of soil erosion as an irreversible land degradation process. This is key to achieve the land degradation neutrality challenge and the sustainability of humankind and natural ecosystems. Agricultural areas are being affected by soil erosion threatening soil quality and, subsequently, food security. Therefore, it is necessary to develop new techniques and methods visually friendly and easy to be accessed to survey and assess the soil erosion concerns. ISUM (Improve Stock Unearthing Method) is a well-contrasted procedure to estimate and map soil mobilisation and erosion rates. To achieve this goal, using the plant graft union as a biomarker conducting in situ topographical measurements along perpendicular transects allow us to i) explain key factors related to the activation of soil erosion processes such as tillage, the age of plantation, parent material or hillslope positions; ii) complete other well-contrasted methods such as RUSLE (Revised Soil Loss Equation), IC (Index of connectivity) or Structure from Motion; and, iii) identify hotspot areas affected by soil depletion, accumulation or mobilisation. In this conference, we will show how we developed a new improvement of this method in different crops (vineyards, citrus, persimmons or almonds), under different environmental conditions (parent material, vine ages, soil management, or slope angle) with diverse geomatic procedures (interpolation methods and geostatistical analysis, topographical measurements and models) using GIS techniques.
\end{abstract}

Key words: soil surface, cartography, mapping techniques, agriculture, soil geography

\section{Resumen:}

Los encargados de diseñar políticas, los trabajadores y los habitantes rurales deben ser conscientes de la relevancia de la erosión del suelo como un proceso irreversible de degradación de la tierra. Esto es clave para lograr la neutralidad en la degradación de la tierra y lograr la sostenibilidad para la humanidad y los ecosistemas naturales. Especialmente, las áreas agrícolas se ven afectadas por la erosión del suelo que amenaza la calidad del suelo y, posteriormente, la seguridad alimentaria. Por tanto, es necesario el desarrollo de nuevas técnicas atractivas visualmente, de fácil manejo y eficientes en la divulgación de los resultados. ISUM (Improve Stock Unearthing Method) es un procedimiento contrastado para estimar y cartografiar las tasas de movilización del suelo y los procesos de erosión. Para lograr este objetivo, el uso del injerto como biomarcador realizando mediciones topográficas in situ (cada $10 \mathrm{~cm}$ ) a lo largo de transectos perpendiculares permite: i) explicar los factores de la activación de los procesos de erosión del suelo como la labranza, la edad de la plantación, material parental o posición en laderas; ii) complementar otros métodos bien contrastados como la RUSLE (Revised Universal Soil Loss Equation), IC (Índice de conectividad) o parcelas de erosión; y, iii) detectar áreas críticas afectadas por el agotamiento, acumulación o movilización del suelo. En esta conferencia, queremos mostrar cómo desarrollamos una nueva mejora de este método en diferentes cultivos (viñedos, cítricos, caquis, y almendros), bajo diferentes condiciones ambientales (roca madre, edades de la vid, manejo del suelo o pendiente) con diversos procedimientos geomáticos (métodos de interpolación y análisis geoestadístico, mediciones y modelos topográficos) mediante técnicas SIG.

Palabras clave: superficie del suelo, cartografía, técnicas cartográficas, agricultura, geografía del suelo 


\section{Introduction}

A powerful agricultural sector being conservative with the soil fertility and its associated ecosystem services is key to sustainable rural development and do not compromise food security (Godfray et al. 2010; Abu Hatab et al. 2019). However, non-sustainable soil management systems in agriculture fields are widespread in many regions of the world because of the use of chemicals, heavy machinery to the soil surface and the intensification of the production (Bijanzadeh and Ghadiri 2006; Bagherzadeh et al. 2018; Bongiorno et al. 2019). Land degradation processes, especially due to the high soil erosion rates are threatening soil fertility, damage soil quality and induce dramatic economic losses after obtaining the final incomes (Niu et al. 2020; Telak and Bogunovic 2020). The lack of sustainable agricultural practices can generate soil erosion processes characterized to be irreversible at medium- and long-term periods.

Nowadays, numerous studies have highlighted the elevated soil erosion rates in traditional plantations such as olives (Beniaich et al. 2020), vineyards (RodrigoComino 2018), cereals (López-Vicente et al. 2015), citrus (Duan et al. 2020), persimmons (Bayat et al. 2019) or apricots (Keesstra et al. 2016). To obtain these results, scholars have used rainfall simulation experiments (Cerdà et al. 2020), modelling techniques (Panagos et al. 2015) or erosion plots (Biddoccu et al. 2020) among other relevant methods. The development of new techniques and methodologies visually friendly and easy to be accessed to survey and assess the soil erosion concerns are necessary and could increase farmers, society and policymakers' awareness.

ISUM (Improve Stock Unearthing Method) is a wellcontrasted procedure to estimate and map soil mobilisation and erosion rates (Rodrigo-Comino and Cerdà 2018). It takes the plant graft union as a biomarker to allow us recognizing soil surface changes and detect hotspots of soil erosion processes. In this communication, we want to introduce ISUM as an in situ topographical tool conducted along perpendicular transects to i) explain key factors related to the activation of soil erosion processes such as tillage, the age of plantation, parent material or hillslope positions; ii) complete other well-contrasted methods such as RUSLE (Revised Soil Loss Equation), IC (Index of connectivity) or erosion plots; and, iii) identify hotspot areas affected by soil depletion, accumulation or mobilisation. In this conference paper, we will show how we developed a new improvement of this method in different crops (vineyards, citrus, persimmons or almonds), under different environmental conditions (parent material, plant ages, soil management, or slope angle) with diverse geomatic procedures (interpolation methods and geostatistical analysis, topographical measurements and models) using GIS techniques.

\section{From SUM to ISUM (improved stock unearthing method)}

\subsection{Definition and procedures}

The Improved Stock Unearthing method (ISUM) has been demonstrated to be a reliable method to assess soil mobilisation rates and understand how soil erosion can affect cultivated areas with grafted plants (RodrigoComino et al. 2019). The results show an accurate assessment of the spatiotemporal evolution of the soil surface level from pluri-annual to pluri-decennial time scales. ISUM is an improved technique based on the first procedures applied in vineyards (Brenot et al. 2006; Casalí et al. 2009) and olives orchards (Vanwalleghem et al. 2010), which was called SUM (Stock Unearthing Method). The pioneer method was similar to other dendro-geomorphology ones (Schnabel 1994) as it considers the distance from the surface soil to the grafted part of the plant, which was confirmed as a passive biomarker of soil surface-level changes since the initial plantation took place (Paroissien et al. 2010).

For example, in vineyards, after the Phylloxera crisis, all the Vitis vinifera were grafted with American scions of controlled species. Other plants are simply grafted to obtain different fruit varieties. However, it is key during this process to understand that the initial distance measured, the day of the plant plantation, between these frontal marks on the graft union and the soil surface remains at the same position if no interventions of external factors such as machinery or extreme rainfall events occur during the first days (Rodrigo-Comino et al. 2016). The current distance between the frontal marks on the graft union (visible by the researcher) and the soil surface can be measured, which can have either an unearthing or buried signal. During the last decade, several scholars stated this main hypothesis based on this relative stable distance at initial conditions (Brenot et al. 2006; Casali et al. 2009). The main weakness of the previous method (SUM) is that it was established on the assumption that the topsoil surface remains almost planar without considering the generation of uncertainties because of the own soil surface roughness, rills, footpaths or wheel tracks signals. Therefore, the most important premise was to include new improvements to consider the diverse changes between each paired-plant or inter-row areas. Therefore, new extra topographical measurements were performed and validated, from each 0.1 to $0.5 \mathrm{~m}$ (Fig. 1). It is necessary that the same trained expert/s perform the topographical measurements to avoid any bias.

\subsection{In situ topographical measurements}

To achieve our goal, we consider each opposite paired plant along each selected inter-row. Then, we first identify where the graft union is and then stretch a measuring tape between these paired points (a meter stick to estimate the vertical distance between the horizontally stretched measuring tape and the current soil surface). We recommend performing measurements at least at $10 \mathrm{~cm}$ intervals. To reduce complications during our field campaign when the graft union is buried, the measuring tape was situated $30 \mathrm{~cm}$ above the graft union. So, for example, if the original soil surface level was levelled up to $2 \mathrm{~cm}$ below the graft union, and thus $32 \mathrm{~cm}$ below the mearing tape level, the difference between $32 \mathrm{~cm}$ and the current measurement at the graft union gives an indication of unburied (negative) or buried (positive) values (Rodrigo-Comino and Cerdà 2018). It is worthy to highlight that the soil roughness under the plants can generate little steps or holes or the grass cover made difficult the visibility of the graft union. Therefore, the grasses were carefully eliminated, or soil softly levelled, not affecting our final sampling collection. 

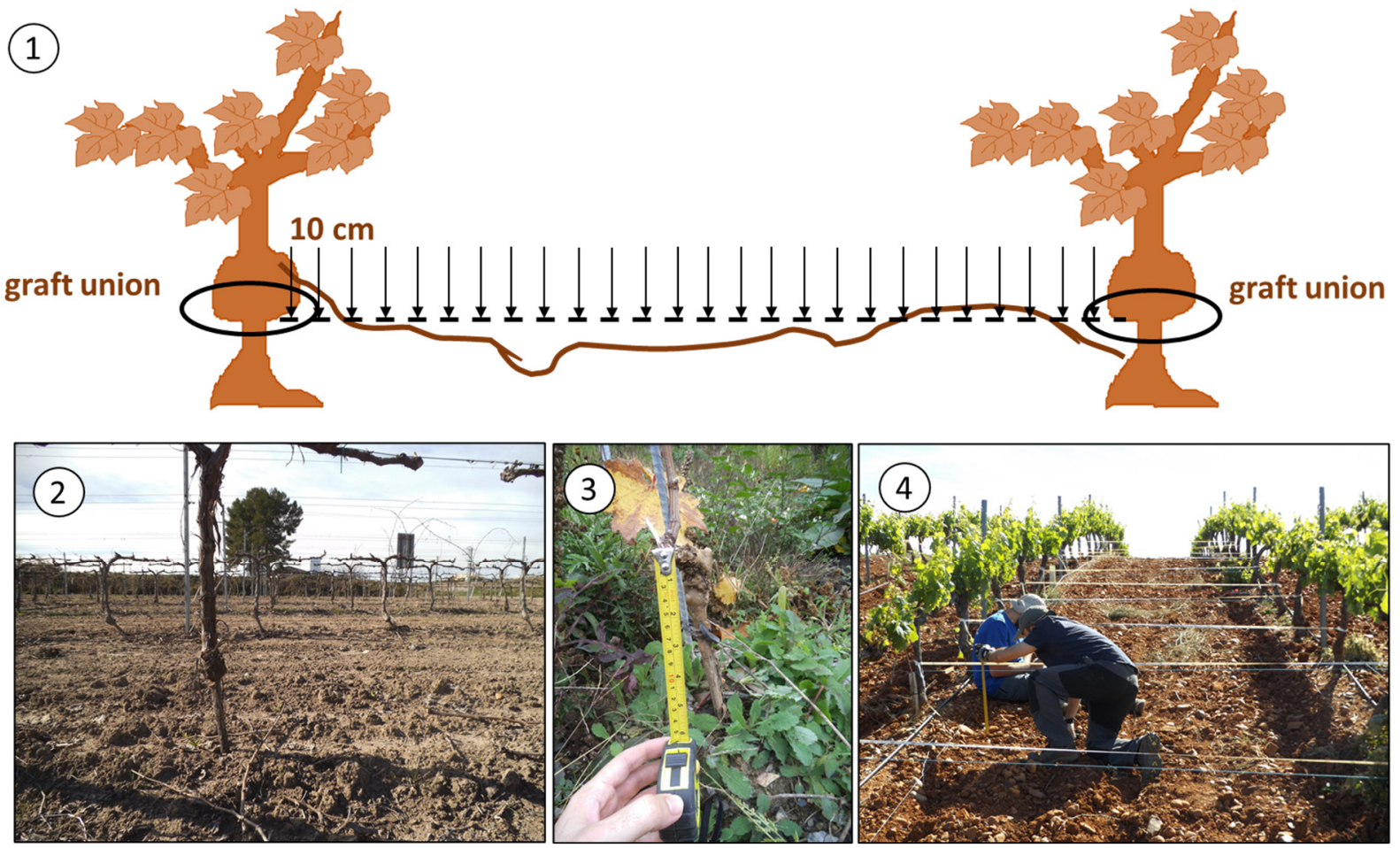

Figure 1: ISUM procedure: 1) sampling strategy; 2) and 3) Graft union examples (8 and 2-years old vineyards in Valencia -Spain- and Trier -Germany-, respectively); 4) Field campaign in Tierra de Barros (Spain).

\subsection{Geostatistic tools: ISUM maps and interpolation methods}

The expected final results must be thematic maps confirmed by warm and cold colours to show the soil surface level changes at the moment when the field campaign took place. First, all the points were organized in an database and then converted into a grid of points using the function "fishnet" of ArcMap 10.5 (ESRI, USA) software. Second, different geostatistical methods most commonly used in soil sciences were tested to generate the best ISUM maps reflecting the topographical changes on the cultivated surface. All data were cross-validated by varying the model parameter values and using different kernel functions. All of these methods should be firstly checked to obtain the best result.

- Inverse distance weighting (IDW).

- Ordinary kriging.

- Empirical Bayesian Kriging (EBK).

- Radial Basis Functions (RBFs).

- Completely regularized spline: spline with tension; multi-quadric; inverse multi-quadric; and thin-plate spline.

Finally, we considered the RMSE (Root-mean-squareerror) and $R^{2}$ (Coefficient of Determination) to validate the models' performance in a cross-validation mode. The smaller the RMSE and the higher the $R^{2}$ the better. In the case that we are not sure how many points must be used to obtain the highest accuracy of the different methods, percentage reductions in the performance statistics of $R^{2} \Delta$ and RMSEA were calculated (Shiri et al. 2017) as Eqs. (2) and (3):
$R^{2} \Delta=\left(\left(R^{2} r e f-R^{2} z\right) / R^{2} r e f\right) * 100$

RMSEA $=(($ RMSEref-RMSEz $) /$ RMSEref $) * 100$

where $R^{2} r e f$ and $R M E S E r e f$ are the reference performance statistics using all of the measuring points of the inter-row pair-plant values, and $R^{2} z$ and $R M S E Z$ are the corresponding values for a reduction in the number of measuring points.

\subsection{Estimations: soil mobilisation rates}

The total soil mobilized in the study area can be estimated in $\mathrm{Mg} \mathrm{ha}^{-1} \mathrm{yr}^{-1}$ using the point measurements obtained from the volume difference between the current soil surface level and the initial soil surface topography at the moment of the plantation. We have to delineate an imaginary polygon whose horizontal sides are defined as the distances between the measuring points used $(10 \mathrm{~cm}$ each one). For example, if the inter-row distance is 190 $\mathrm{cm}$, and it will mean the first and last of the 17 measuring points are $10 \mathrm{~cm}$ from the graft unions. The height of the polygon's side will be the distance between the graft union and the inter-row surface levels, taking into account the visible current passive biomark on the plant (RodrigoComino et al. 2015). Finally, the soil mobilisation can be estimated from the erosion-deposition $(E R)$ equation developed by (Paroissien et al. 2010):

$E R=V^{*} B D /(S * A)$

where $V\left(\mathrm{~m}^{3}\right)$ represents the volume, $S$ (measured in ha) means the total area for the considered field unit, $A$ (years) is the age of the plants and $B D$ is the soil bulk density (measured in $\mathrm{g} \mathrm{cm}^{-3}$ ). The reference value of the soil bulk density was taken as the mean soil bulk density 
of the different soil samples collected along the row and inter-row area.

\section{Results obtained considering different crops, methods and factors}

\subsection{Vineyards}

In Table 1, we present the soil mobilisation rates obtained under different conditions in vineyards located in the Valencia region including 5 points along the transects. These values corresponded to the first approaches conducted to verify the use of extra measurements in the inter-row area (Fig. 2). The results confirmed for vineyards the negative impacts of tillage on the soil, the intensification of the erosion processes due to the differences of the age of plantation, the differences among slope positions and influence of the parent material (Martínez-Casasnovas and Ramos 2009; Mohammadkhan et al. 2011; Bogunović et al. 2014; Marques et al. 2020).

Table 1: Soil erosion in vineyards considering different factors and locations in the Valencia region using 5 points. Soil mobilisation with negative values represent soil loss and positive accumulation.

\begin{tabular}{c|c|c} 
Types & $M g h \mathrm{a}^{-1} \mathrm{yr}^{-1}$ & Reference \\
\hline $\begin{array}{c}\text { Tilled plot } \\
\text { old) }\end{array}$ & -2.5 & $\begin{array}{c}\text { Rodrigo-Comino } \\
\text { and Cerdà (2018) } \\
\text { Rodrigo-Comino } \\
\text { et al. (2018a) }\end{array}$ \\
$\begin{array}{c}\text { Marls (8 years old) } \\
\text { Tilled plot (shoulder) }\end{array}$ & -4.35 & $\begin{array}{c}\text { Rodrigo-Comino } \\
\text { et al. (2018b) }\end{array}$ \\
$\begin{array}{c}\text { Tilled plot (bakcslope) } \\
\text { Tilled plot (shoulder) }\end{array}$ & +2.8 & +13.3 \\
$\begin{array}{c}\text { Tilled plot (2 years old) } \\
\text { Tilled plot (25 years } \\
\text { old) }\end{array}$ & -8.16 & $\begin{array}{c}\text { Rodrigo-Comino, } \\
\text { et al. (2017) }\end{array}$ \\
& -1.61 &
\end{tabular}

\subsection{Other grafted plants and soil processes using ISUM}

ISUM was also used to estimate other soil processes such as soil compaction, roughness and runoff in other grafted plants (Table 2). For example, considering the Diospyros kaki species, the uses of flood irrigation vs tillage were compared, and the results showed 52.6 vs $31.9 \mathrm{Mg} \mathrm{ha}^{-1} \mathrm{yr}^{-1}$, respectively. In persimmon plantations, Bayat et al. (2019) detected differences in soil mobilisation rates between inter-row and row areas, reaching up to more than $20 \mathrm{Mg} \mathrm{ha}^{-1} \mathrm{yr}^{-1}$.

ISUM also allows measuring other soil parameters. Moradi et al. 2020) compared the use of bulk density rings and ISUM to assess differences in soil compaction and consolidation in 25-years old plantation. The results showed differences of $2 \mathrm{~mm}$ among methods, 12 (ring core sampling) and $14 \mathrm{~mm} \mathrm{yr}^{-1}$ (ISUM). Also, ISUM was useful to assess specific parameters related to the RUSLE (Revised Universal Soil Loss Equation) such as L Factor and soil roughness to observe potential influences of holes and soil accumulation areas to reduce or accelerate soil mobilisation rates (da Silva et al. 2019; Rodrigo-Comino et al. 2020).

\subsection{ISUM combined with other methods to understand soil mobilisation}

In Figure 3, we show how ISUM was used with success combined with other well-contrasted methods such as index of connectivity (Borselli et al. 2008), RUSLE (Renard et al. 1991) or Structure from Motion or SfM (Westoby et al. 2012). All of these methods allowed us to complete information about mobile parameters through maps (Fig. 3.1), new calculations to interpret our obtained results (Fig. 3.2) and accurate images to detect hotspots (Fig. 3.3).

\section{Conclusions and further research}

ISUM is an easy-to-apply, rapid and non-expensive tool to assess soil erosion processes, estimate soil mobilisation and generate visually friendly maps in areas cultivated with grafted plants such as vineyards, persimmons, citrus, etc. Our topographical in situ measurements along perpendicular transects between paired plants showed a procedure that can be used over the world and those data are comparable among research groups. In this communication, we demonstrated that this method allows being improved and completed with other techniques, which can add new information about soil erosion processes. These tasks are keys to increasing public awareness among policymakers, stakeholders, and even farmers involved. Further research can be developed using drones, testing organic farming plots or conducting measurements during different months to observe the variations among seasons, meteorological and phenological scenarios.

Table 2: Soil erosion in other orchards considering different factors and locations in the Valencia region. SM/Factor: soil management system or factor studied.

\begin{tabular}{|c|c|c|c|c|}
\hline Crop & SM/Factor & Age & Results & Reference \\
\hline Persimmon & Flood irrigation vs tillage & 25 & 52.6 vs $31.9 \mathrm{Mg} \mathrm{ha}^{-1} \mathrm{yr}^{-1}$ & Rodrigo-Comino et al. (2020) \\
\hline Persimmon & Soil compaction & 3 & $14 \mathrm{~mm}$ lowering & Moradi et al. (2020) \\
\hline Citrus & Transect Length Index (TLI) & $8 / 25$ & $8.3 \mathrm{~mm} \mathrm{yr}^{-1}$ & Rodrigo-Comino et al. (2020) \\
\hline Persimmon & $\begin{array}{l}\text { Transect Length Index (TLI) } \\
\text { and Soil roughness }\end{array}$ & 18 & $\begin{array}{l}69 \% \text { of the total area slightly depressed } \\
\text { and } 95 \% \text { random orientation }\end{array}$ & da Silva et al. (2019) \\
\hline Persimmon & Inter-row vs row & 25 & 58.9 vs $37.2 \mathrm{Mg} \mathrm{ha}^{-1} \mathrm{yr}^{-1}$ & Bayat et al. (2019) \\
\hline
\end{tabular}



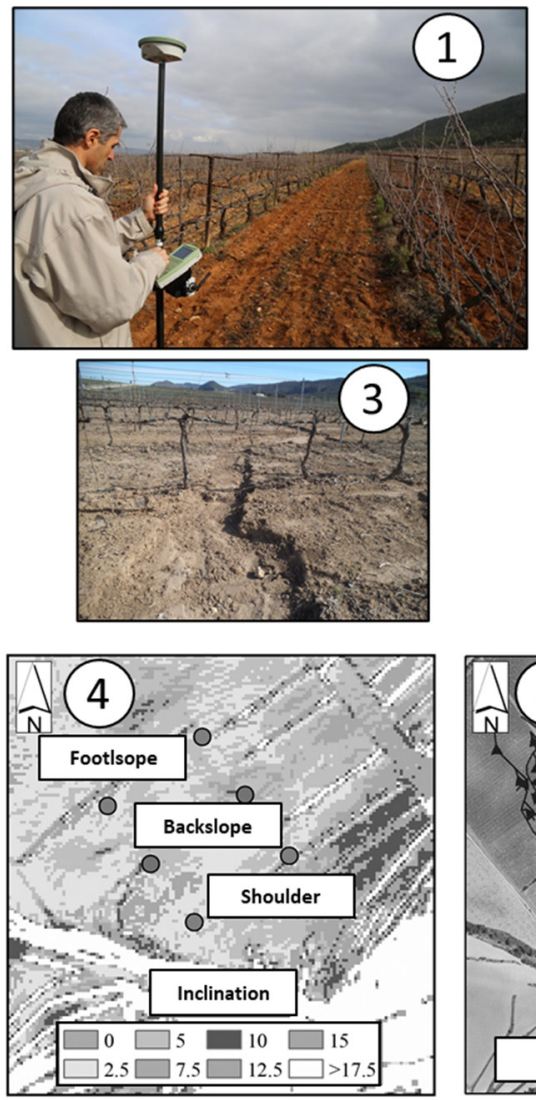

Soil surface level

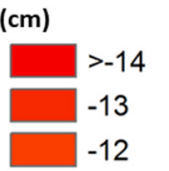

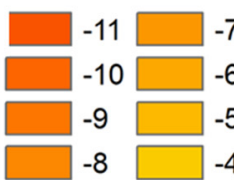

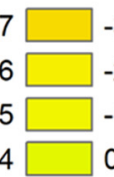

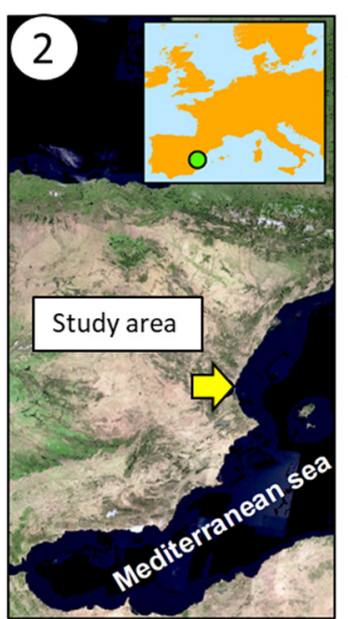

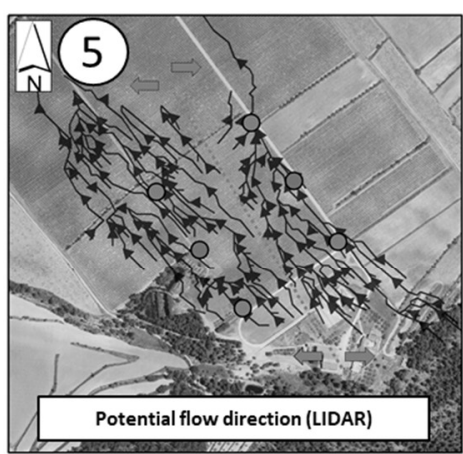

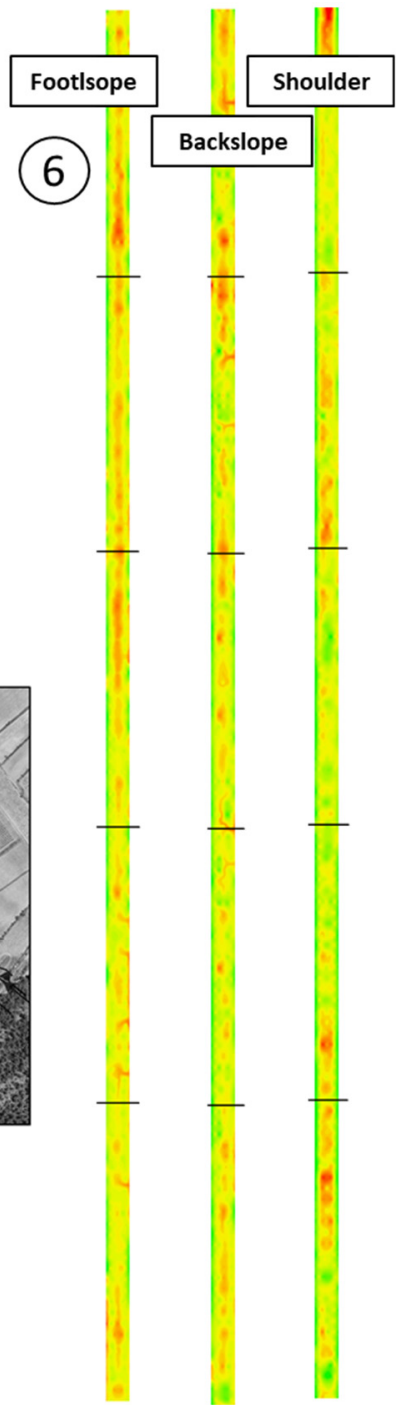

Figure 2: Example ISUM map considering different slope positions: 1) GPS sampling points; 2) Localisation; 3) Soil erosion process (rill); 4) Transects per slope position; 5) Potential flow direction map; 6) ISUM map.
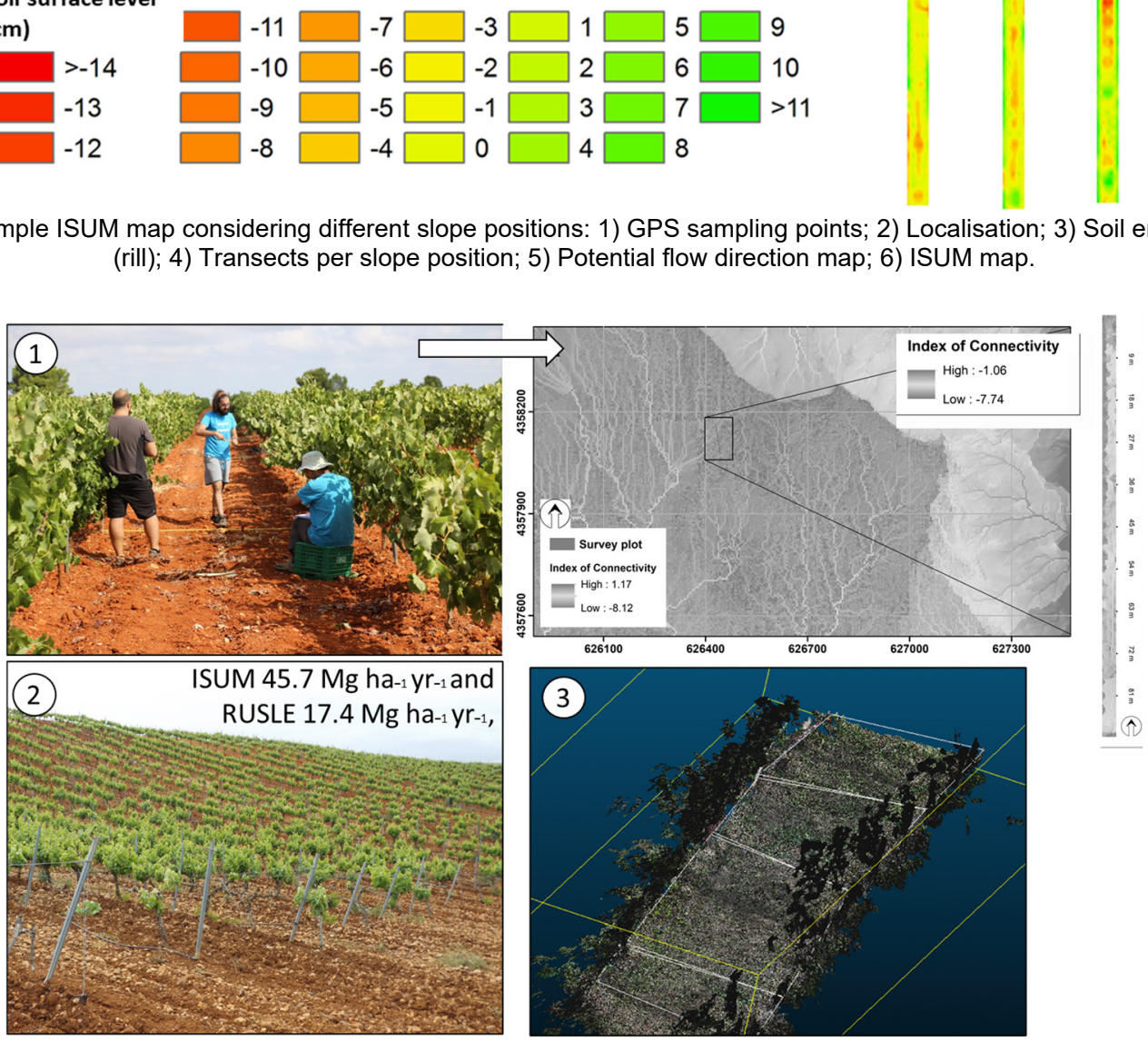

Figure 3: Examples of ISUM applications. 1) Vineyard located in Castilla la Mancha in Spain and Connectivity index map (RodrigoComino et al. 2020); 2) Vineyard in Tierra de Barros, Extremadura and RUSLE+ISUM calculations (Barrena-González et al. 2020); 3) Image extracted from SfM techniques (Remke et al. 2018). 


\section{References}

HATAB, A. A., CAVINATO, M. E. R., LINDEMER, A., and LAGERKVIST, C. J., 2019. Urban sprawl, food security and agricultural systems in developing countries: A systematic review of the literature. Cities, 94, pp. 129-142. DOI: 10.1016/j.cities.2019.06.001.

BAGHERZADEH, A., GHOLIZADEH, A., and KESHAVARZI, A., 2018. Assessment of soil fertility index for potato production using integrated Fuzzy and AHP approaches, Northeast of Iran. Eurasian Journal of Soil Science, 7(3), pp. 203-212.

BARRENA-GONZÁlEZ, J., RODRIGO-COMINO, J., GYASI-AGYEI, Y., PULIDO FERNÁNDEZ, M., and CERDÀ, A., 2020. Applying the RUSLE and ISUM in the Tierra de Barros Vineyards (Extremadura, Spain) to Estimate Soil Mobilisation Rates. Land, 9(3), p. 93. DOI: 10.3390/land9030093.

BAYAT, F., MONFARED, A. B., JAHANSOOZ, M. R., ESPARZA, E. T., KESHAVARZI, A., MORERA, A. G., and CERDA, A., 2019. Analyzing long-term soil erosion in a ridge-shaped persimmon plantation in eastern Spain by means of ISUM measurements. CATENA, 183, p. 104176. DOI: 10.1016/j.catena.2019.104176.

BENIAICH, A., SILVA, M. L. N., GUIMARÃES, D. V., BISPO, D. F. A., AVANZI, J. C., CURI, N., and DONDEYNE, S., 2020. Assessment of soil erosion in olive orchards (Olea europaea L.) under cover crops management systems in the tropical region of Brazil. Revista Brasileira de Ciência do Solo, 44. DOI: 10.36783/18069657rbcs20190088.

BIDDOCCU, M., GUZMAN, G., CAPELLO, G., THIELKE, T., STRAUSS, P., WINTER, S., and GOMEZ, J. A., 2020. Evaluation of soil erosion risk and identification of soil cover and management factor (C) for RUSLE in European vineyards with different soil management. International Soil and Water Conservation Research, 8(4), pp. 337-353. DOI: 10.1016/j.iswcr.2020.07.003.

BIJANZADEH, E., and GHADIRI, H., 2006. Effect of separate and combined treatments of herbicides on weed control and corn (Zea mays) yield. Weed Technology, 20(3), pp. 640-645.

BOGUNOVIĆ, I., KISIĆ, I., and JURISIĆ, A., 2014. Soil Compaction under Different Tillage System on Stagnic Luvisols. Agriculturae Conspectus Scientificus, 79(1), pp. 57-63.

BONGIORNO, G., BÜNEMANN, E. K., OGUEJIOFOR, C. U., MEIER, J., GORT, G., COMANS, R., and DE GOEDE, R., 2019. Sensitivity of labile carbon fractions to tillage and organic matter management and their potential as comprehensive soil quality indicators across pedoclimatic conditions in Europe. Ecological Indicators, 99, pp. 38-50. DOI: 10.1016/j.ecolind.2018.12.008.

BORSELLI, L., CASSI, P., and TORRI, D., 2008. Prolegomena to sediment and flow connectivity in the landscape: A GIS and field numerical assessment. CATENA, 75(3), pp. 268-277. DOI: 10.1016/j.catena.2008.07.006.

BRENOT, J., QUIQUEREZ, A., PETIT, C., GARCIA, J. P., and DAVY, P., 2006. Soil erosion rates in \{Burgundian\} vineyards. Bolletino società geologica Italiana.

CASALÍ, J., GIMÉNEZ, R., DE SANTISTEBAN, L., ÁLVAREZ-MOZOS, J., MENA, J., and DE LERSUNDI, J. D. V., 2009. Determination of long-term erosion rates in vineyards of Navarre (Spain) using botanical benchmarks. CATENA, 78(1), pp. 12-19. DOI: 10.1016/j.catena.2009.02.015.

CERDÀ, A., RODRIGO-COMINO, J., YAKUPOĞLU, T., DINDAROĞLU, T., TEROL, E., MORA-NAVARRO, G., and DALIAKOPOULOS, I. N., 2020. Tillage Versus No-Tillage. Soil Properties and Hydrology in an Organic Persimmon Farm in Eastern Iberian Peninsula. Water, 12(6), p. 1539. DOI: 10.3390/w12061539.

DUAN, J., LIU, Y. J., YANG, J., TANG, C. J., AND SHI, Z. H., 2020. Role of groundcover management in controlling soil erosion under extreme rainfall in citrus orchards of southern China. Journal of Hydrology, 582, p. 124290. DOI: 10.1016/j.jhydrol.2019.124290.

GODFRAY, H. C. J., BEDDINGTON, J. R., CRUTE, I. R., HADDAD, L., LAWRENCE, D., MUIR, J. F., and TOULMIN, C., 2010. Food Security: The Challenge of Feeding 9 Billion People. Science, 327(5967), pp. 812-818. DOI: 10.1126/science.1185383.

KEESSTRA, S., PEREIRA, P., NOVARA, A., BREVIK, E. C., AZORIN-MOLINA, C., PARRAS-ALCÁNTARA, L., and CERDÀ, A., 2016. Effects of soil management techniques on soil water erosion in apricot orchards. Science of the Total Environment, 551-552, pp. 357-366. DOI: 10.1016/j.scitotenv.2016.01.182.

LÓPEZ-VICENTE, M., QUIJANO, L., GASPAR, L., PALAZÓN, L., and NAVAS, A., 2015. (2015. Severe soil erosion during a 3-day exceptional rainfall event: combining modelling and field data for a fallow cereal field. Hydrological Processes, 29(10), pp. 2358-2372. DOI: 10.1002/hyp.10370.

MARQUES, M. J., RUIZ-COLMENERO, M., BIENES, R., GARCÍA-DÍAZ, A., and SASTRE, B., 2020. Effects of a Permanent Soil Cover on Water Dynamics and Wine Characteristics in a Steep Vineyard in the Central Spain. Air, Soil and Water Research, 13. DOI: 10.1177/1178622120948069.

MARTÍNEZ-CASASNOVAS, J. A., and CONCEPCION RAMOS, M., 2009. Soil alteration due to erosion, ploughing and levelling of vineyards in north east Spain. Soil Use and Management, 25(2), pp. 183-192. 
MOHAMMADKHAN, S., AHMADI, H., and JAFARI, M., 2011. Relationship between soil erosion, slope, parent material, and distance to road (Case study: Latian Watershed, Iran). Arabian Journal of Geosciences, 4(1-2), pp. 331-338. DOI: 10.1007/s12517-010-0197-z.

MORADI, E., RODRIGO-COMINO, J., TEROL, E., MORA-NAVARRO, G., MARCO DA SILVA, A., N DALIAKOPOULOS, I., and CERDÀ, A., 2020. Quantifying Soil Compaction in Persimmon Orchards Using ISUM (Improved Stock Unearthing Method) and Core Sampling Methods. Agriculture, 10(7), p. 266. DOI: 10.3390/agriculture10070266.

NIU, Y. H., LI, X., WANG, H. X., LIU, Y. J., SHI, Z. H., and WANG, L., 2020. Soil erosion-related transport of neonicotinoids in new citrus orchards. Agriculture, Ecosystems \& Environment, 290. DOI: 10.1016/j.agee.2019.106776.

PANAGOS, P., BORRELli, P., MEUSBURGER, K., VAN DER ZANDEN, E. H., POESEN, J., and ALEWELL, C., 2015. Modelling the effect of support practices (P-factor) on the reduction of soil erosion by water at European scale. Environmental Science \& Policy, 51, pp. 23-34. DOI: 10.1016/j.envsci.2015.03.012.

PAROISSIEN, J.-B., LAGACHERIE, P., and LE BISSONNAIS, Y., 2010. A regional-scale study of multi-decennial erosion of vineyard fields using vine-stock unearthing-burying measurements. Catena, 82(3), pp. 159-168. DOI: 10.1016/j.catena.2010.06.002.

REMKE, A., RODRIGO-COMINO, J., GYASI-AGYEI, Y., CERDÀ, A., and RIES, J. B., 2018. Combining the Stock Unearthing Method and Structure-from-Motion Photogrammetry for a Gapless Estimation of Soil Mobilisation in Vineyards. ISPRS International Journal of Geo-Information, 7(12), p. 461. DOI: 10.3390/ijgi7120461.

RENARD, K. G., FOSTER, G. R., WEESIES, G. A., and PORTER, J. P., 1991. RUSLE: revised universal soil loss equation. Journal of Soil and Water Conservation, 46, pp. 30-33.

RODRIGO-COMINO, J., BRINGS, C., LASSU, T., ISERLOH, T., SENCIALES, J. M., MARTÍNEZ MURILLO, J. F., and RIES, J. B., 2015. Rainfall and human activity impacts on soil losses and rill erosion in vineyards (Ruwer Valley, Germany). Solid Earth, 6, pp. 823-837. DOI: 10.5194/se-6-823-2015.

RODRIGO-COMINO, J., QUIQUEREZ, A., FOLLAIN, S., RACLOT, D., LE BISSONNAIS, Y., CASALÍ, J., and RIES, J. B., 2016. Soil erosion in sloping vineyards assessed by using botanical indicators and sediment collectors in the RuwerMosel valley. Agriculture, Ecosystems \& Environment, 233, pp. 158-170. DOI: 10.1016/j.agee.2016.09.009.

RODRIGO-COMINO, J., NOVARA, A., GYASI-AGYEI, Y., TEROL, E., and CERDÀ, A., 2018a. Effects of parent material on soil erosion within Mediterranean new vineyard plantations. Engineering Geology, 246, pp. 255-261. DOI: 10.1016/j.enggeo.2018.10.006.

RODRIGO-COMINO, J., 2018. Five decades of soil erosion research in "terroir". The State-of-the-Art. Earth-Science Reviews, 179, pp. 436-447. DOI: 10.1016/j.earscirev.2018.02.014.

RODRIGO-COMINO, J., KESHAVARZI, A., ZERAATPISHEH, M., GYASI-AGYEI, Y., and CERDÀ, A., 2019. Determining the best ISUM (Improved stock unearthing Method) sampling point number to model long-term soil transport and microtopographical changes in vineyards. Computers and Electronics in Agriculture, 159, pp. 147-156. DOI: 10.1016/j.compag.2019.03.007.

RODRIGO-COMINO, J., DA SILVA, A. M., MORADI, E., TEROL, E., and CERDÀ, A., 2020. Improved Stock Unearthing Method (ISUM) as a tool to determine the value of alternative topographic factors in estimating inter-row soil mobilisation in citrus orchardssion in orchards. Spanish Journal of Soil Science, 10(1). DOI: 10.3232/SJSS.2020.V10.N1.05.

RODRIGO-COMINO, J., LUCAS-BORJA, M. E., BERTALAN, L., and CERDÀ, A., 2020. Integrating in situ measurements of an index of connectivity to assess soil erosion processes in vineyards. Hydrological Sciences Journal. DOI: 10.1080/02626667.2020.1711914.

RODRIGO-COMINO, J., PONSODA-CARRERES, M., SALESA, D., TEROL, E., GYASI-AGYEI, Y., and CERDÀ, A., 2020. Soil erosion processes in subtropical plantations (Diospyros kaki) managed under flood irrigation in Eastern Spain. Singapore Journal of Tropical Geography, 41(1), pp. 120-135. DOI: 10.1111/sjtg.12307.

RODRIGO-COMINO, J., BREVIK, E., and CERDÀ, A., 2017. The age of vines as a controlling factor of soil erosion processes in Mediterranean vineyards. Science of The Total Environment. DOI: 10.1016/j.scitotenv.2017.10.204.

RODRIGO-COMINO, J., and CERDÀ, A., 2018. Improving stock unearthing method to measure soil erosion rates in vineyards. Ecological Indicators, 85(Supplement C), pp. 509-517. DOI: 10.1016/j.ecolind.2017.10.042.

RODRIGO-COMINO, J., KEESSTRA, S. D., and CERDÀ, A., 2018b. Connectivity assessment in Mediterranean vineyards using improved stock unearthing method, LiDAR and soil erosion field surveys. Earth Surface Processes and Landforms, 43(10), pp. 2193-2206. DOI: 10.1002/esp.4385.

SCHNABEL, S., 1994. Using botanical evidence for the determination of erosion rates in semi-arid tropical areas. Advances in GeoEcology, 27, pp. 31-45.

SHIRI, J., KESHAVARZI, A., KISI, O., ITURRARAN-VIVEROS, U., BAGHERZADEH, A., MOUSAVI, R., and KARIMI, S., 2017. Modeling Soil Cation Exchange Capacity Using Soil Parameters: Assessing the Heuristic Models. Computers and Electronics in Agriculture, 135, pp. 242-251. DOI: 10.1016/j.compag.2017.02.016. 
DA SILVA, A. M., MORADI, E., RODRIGO-COMINO, J., and CERDÀ, A., 2019. Spatial variability of soil roughness in persimmon plantations: A new combined ISUM (improved stock unearthing method) approach. Ecological Indicators, 106. DOI: $10.1016 / \mathrm{j}$. ecolind.2019.105528.

TELAK, L. J., and BOGUNOVIC, I., 2020. Tillage-induced impacts on the soil properties, soil water erosion, and loss of nutrients in the vineyard (Central Croatia). Journal of Central European Agriculture, 21(3), pp. 589-601. DOI: 10.5513/JCEA01/21.3.2810.

VANWALLEGHEM, T., LAGUNA, A., GIRÁLDEZ, J. V., and JIMÉNEZ-HORNERO, F. J., 2010. Applying a simple methodology to assess historical soil erosion in olive orchards. Geomorphology, 114(3), pp. 294-302. DOI: 10.1016/j.geomorph.2009.07.010.

WESTOBY, M. J., BRASINGTON, J., GLASSER, N. F., HAMBREY, M. J., and REYNOLDS, J. M., 2012. "Structure-fromMotion" photogrammetry: A low-cost, effective tool for geoscience applications. Geomorphology, 179, pp. 300-314. DOI: 10.1016/j.geomorph.2012.08.021. 